\title{
COLORIMETRIC TEST FOR THE MONITORING OF MICROCYSTINS IN CYANOBACTERIAL CULTURE AND ENVIRONMENTAL SAMPLES FROM SOUTHEAST - BRAZIL
}

\author{
Vanessa P.S. Almeida ${ }^{1 *}$; Karina Cogo ${ }^{2}$; Siu M. Tsai ${ }^{3}$; David H. Moon ${ }^{4}$ \\ ${ }^{1}$ Laboratório de Ecologia Isotópica, Centro de Energia Nuclear na Agricultura, Universidade de São Paulo, Piracicaba, SP, Brasil; \\ ${ }^{2}$ Universidade Estadual de Campinas, Piracicaba, SP, Brasil; ${ }^{3}$ Laboratório de Biologia Celular e Molecular, Centro de Energia \\ Nuclear na Agricultura, Universidade de São Paulo, Piracicaba, SP, Brasil; ${ }^{4}$ Departamento de Genética, Escola Superior de \\ Agricultura Luiz de Queiroz, Universidade de São Paulo, Piracicaba, São Paulo
}

Submitted: April 15, 2005; Returned to authors for corrections: October 06, 2005; Approved: February 26, 2006

\begin{abstract}
Microcystins are hepatotoxic heptapeptides produced by some cyanobacterial genera under determined physico-chemical conditions in the environment, which are responsible for the intoxication and death of animals and humans. The detection of microcystins in potable water or recreational water is not carried out routinely in the majority of Brazilian states. The protein phosphatase 1 (PP1) inhibition test is a simple, rapid and reproducible colorimetric method. The applicability of the PP1 inhibition test was tested using Microcystis aeruginosa (strain 1, UFRJ- toxin producer) grown under controlled light and temperature condition $(12 / 12 \mathrm{~h}$ light/dark using $30 \mu \mathrm{E} \cdot \mathrm{m}^{2} \cdot \mathrm{s}^{-1}$ at $\left.23^{\circ} \mathrm{C}\right)$ in a bioreactor. The total concentrations of $\mathrm{P}(24,6$ and $4 \mu \mathrm{M})$ and $\mathrm{Fe}$ ( 4 and $1 \mu \mathrm{M}$ ) were varied in ASM-1medium and their effects on the growth rates and toxin production were analyzed. A standard curve of PP1 inhibition by microcystin-LR reached detection limit of $0.01 \mathrm{ng} \cdot \mathrm{mL}^{-1}$. Under the highest concentrations of $\mathrm{P}(24 \mu \mathrm{M})$ and $\mathrm{Fe}(4 \mu \mathrm{M})$, the production of microcystin was detected throughout the growth experiment. The highest concentration of microcystin was observed at $6 \mu \mathrm{M} \mathrm{P}$ while at $1 \mu \mathrm{M} \mathrm{Fe}$, PP1 inhibition was not detected. Samples from environmental blooms in water reservoirs used for human and animal consumption, from southeast Brazil (Belo Horizonte/MG), were tested and quantified for microcystin presence by the PP1 colorimetric test. The concentration of microcystin varied from undetectable to 100 ng. $\mathrm{mL}^{-1}$ in the environmental samples with Microcistis flos-aquae as the predominant cyanobacterial strain.
\end{abstract}

Key words: phosphatase protein, Microcystis aeruginosa, inhibition and environment

\section{INTRODUCTION}

The availability and quality of freshwater has been a matter of concern with many questions regarding the effect of pollution on human health, due to the lack of basic treatment of both industrial and household effluents. The contamination of water for human consumption with microcystin (MC), a toxin produced by many genera of cyanobacteria (blue-green algae) forming bloom and scum in freshwater, have been associated with eutrophication of the water body (i.e. increase in nutrients, especially phosphorus and nitrogen).
The main toxic cyanobacteria genera include Anabaena, Aphanizomenon, Nodularia and Microcystis, which produce a hepatotoxin responsible for animal deaths and hazardous for humans $(4,6,7)$. Microcystins are cyclic-heptapeptides, characterized by an unusual amino acid residue (ADDA), which is essential in toxicity. Microcystins are named by two amino acids that occupy the variable positions $\mathrm{X}$ and $\mathrm{Y}$ (e.g. MC-RR, arginine arginine). Both these variable amino acids influence the toxicity of the heptapeptide (28). Not all strains of Microcystis aeruginosa produce toxins, but all strains have genes for peptide synthetases, but only the toxic strains have the specific peptide

*Corresponding Author. Mailing address: Laboratório de Ecologia Isotópica, Centro de Energia Nuclear na Agricultura, Universidade de São Paulo, Av. Centenário, 303. Piracicaba. 13400-970, São Paulo, Brasil. Fax: (+5519) 3434-9210. E-mail: vpsilvei@cena.usp.br 
synthetases responsible for microcystin production (24). Besides this, microcystin production may be controlled by environmental conditions $(4,23,27)$.

The environmental factors which influence toxic bloom formation in water bodies are temperature, $\mathrm{pH}$, high light intensity, and nutrient concentrations, especially nitrogen, phosphorus and iron $(9,18,28)$.

Poisoning by $M$. aeruginosa has been described in several countries. In Brazil, 50 hemodialysis patients died as a result of the presence of microcystins in water (10) and in China microcystins are thought to be a cause the higher than normal levels of primary liver cancer (40). The acceptable limit of MCLR in treated drinking water suggested by Falconer (12) is $1 \mu \mathrm{g} . \mathrm{L}^{-1}$, and this concentration correspond to $5.10^{3}$ cells of microcystis. $\mathrm{mL}^{1}$. The $\mathrm{MC}$ target in humans is the liver in which phosphatase protein 1 and $2 \mathrm{~A}$ inhibition occurs, which result in a hyper-phosphorylation, causing hemorrhage (11).

Microcystins have an $\mathrm{LD}_{50}$ in mice ranging from 50 to 250 $\mu \mathrm{g} \cdot \mathrm{kg}^{-1}$ of body weight intraperitoneally and $5000 \mu \mathrm{g} \cdot \mathrm{kg}^{-1}$ to body weight orally (7). Mouse bioassays have been used to detect toxicity (28) coupled with other methodologies which also allow quantification such as the protein phosphatase inhibition test, HPLC, ELISA and molecular techniques (10).

Ward et al. (36) used the protein phosphatase type 1 inhibition test (PP1) and obtained rapid quantification of the toxin microcystin in a large number of samples. This test is easy to perform and showed a good correlation with the standard tests (HPLC and bioassays) on axenic cultures and bloom samples. Various groups $(1,2,15,17,24,30,39)$ have shown this test to be suitable for the monitoring of water destined for human consumption, as well as the detection of microcystins in cyanobacterial cultures and blooms. The disadvantage of the method is that it does not give any indication of which congeners are present in a mixture of microcystin toxins.

As hepatotoxins dissolved in water are not removed by conventional water treatment in 1988 to the WHO (World Health Organization) proposed a consumption guideline of $1 \mu \mathrm{g}$ of LR-microcystin $\mathrm{L}^{-1}$. day ${ }^{-1}$ in treated drinking water. This limit in treated drinking water has been globally accepted $(16,21)$ with Brazil legalizing this limit in 2004 (3). The sensitivity of the PP1 inhibition test for detection of hepatotoxins is 0.2$1 \mu \mathrm{g} . \mathrm{L}^{-1}$.day ${ }^{-1}$.

In the present study, growth experiments in batch cultures of Microcystis sp. (strain1. UFRJ) were carried out with the aim evaluating the effect of $\mathrm{P}$ (phosphorus) and Fe (iron) on the growth and microcystin production of the cells. The sanitation company of Minas Gerais collected environmental samples from Belo Horizonte water bodies (8) and previously detected microcystin using HPLC and a mouse bioassay. To detect the microcystin produced under culture conditions and to confirm its presence in environmental samples the protein phosphatase (type 1) test was used.

\section{MATERIALS AND METHODS}

\section{Culture Conditions}

Axenic, microcystin producing Microcystis aeruginosa (strain 1) was acquired from the culture collection of Universidade Federal do Rio de Janeiro-UFRJ. The inoculum was produced by growing $M$. aeruginosa in $50 \mathrm{~mL}$ of ASM-1 medium in a $250 \mathrm{~mL}$ Erlenmeyer flask and incubated at 7 days under controlled conditions. Batch cultures were maintained at a controlled temperature of $25 \pm 1^{\circ} \mathrm{C}$ and light intensity of $30 \mu \mathrm{E} \cdot \mathrm{m}^{-2} \cdot \mathrm{s}^{-1}$ (cool white fluorescent light) using a $12 \mathrm{~h}$ photoperiod.

All glassware was soaked in $2 \% \mathrm{NaOH}$ overnight, thoroughly rinsed in sterile Milli-Q water, soaked in $2 \% \mathrm{HCl}$ overnight and thoroughly rinsed in Milli-Q water before being sterilized. The inoculum was introduced into six liters of ASM-1 medium (14) and grown in batch under the above conditions with aeration. The following experiments were set up in order to test the effects of phosphorus and iron on growth and microcystin production: (a) Sterile ASM-1 medium (standard conditions, $24 \mu \mathrm{M} P$ and $4 \mu \mathrm{M} \mathrm{Fe}$ ); (b) Sterile ASM-1 medium with $6 \mu \mathrm{M}$ P and $4 \mu \mathrm{M} \mathrm{Fe}$; (c) Sterile ASM-1 medium with $2 \mu \mathrm{M} \mathrm{P}$ and $4 \mu \mathrm{M} \mathrm{Fe}$; and (d) Sterile ASM-1 medium with $24 \mu \mathrm{M}$ P and $1 \mu \mathrm{M}$ Fe. A stock solution of ferric chloride was prepared and added aseptically to final concentrations of 4 and $1 \mu \mathrm{M}$. The vials of stock solutions were prepared at same time to medium preparation. Phosphate limited conditions were obtained by decreasing the stock solution of $\mathrm{Na}_{2} \mathrm{HPO}_{4}$ to final concentration 24,6 and $2 \mu \mathrm{M}$ P. Three growth experiments were carried out for each set of nutrient conditions and the result expressed as the mean of the three growth curves.

Growth was monitored by measuring dry weight at each sampling day by filtering $50 \mathrm{~mL}$ of the culture and the filter dried and weighed using the Denver Instruments 2 HP balance, with infra red at $100^{\circ} \mathrm{C}$.

Growth rate and doubling time were calculated by equations described by White (38). The doubling time of each of the new growth curves under various nutrient conditions, using $M$. aeruginosa (strain 1).

\section{Protein Phosphatase (type 1) inhibition test - PP1 test}

Following the procedure by Ward et al. (36), the pellet of $M$. aeruginosa was dissolved in $10 \mathrm{~mL}$ methanol $70 \%$ and submitted to the PP1 test. For toxin analysis, the cells were harvested from $50 \mathrm{~mL}$ of culture at $3000 \mathrm{rpm}$ for $20 \mathrm{~min}$ at $20^{\circ} \mathrm{C}$, the supernatant was removed and the pellet were frozen and lyophilized. The toxins were extracted from the freeze-dried cells with methanol $70 \%$ for the phosphatase test $(50 \mathrm{mg}$ of lyophilized cells and $1.5 \mathrm{~mL}$ of methanol 70\%). The catalytic subunit of protein phosphates 1 , rabbit muscle, recombinant and expressed in Escherichia coli was obtained from Calbiochem (Lot B26090 - 539493-CA). 
The PP1 was diluted in buffer $(1 \mathrm{~mL})$ containing $50 \mathrm{mM}$ Tris$\mathrm{HCl}, 1.0 \mathrm{mM} \mathrm{Na}{ }_{2}$ EDTA, $2 \mathrm{Mm} \mathrm{MnCl}_{2}, 0.5$ g.L $\mathrm{L}^{-1}$ of $1 \%$ bovine serum albumin (BSA Fraction V, Sigma) and $0.1 \%(\mathrm{v} / \mathrm{v})$ mercaptoethanol, $\mathrm{pH}$ 7.4. The substrate, $\mathrm{p}$-NitroPhenolPhosphate (pNPP $20 \mathrm{Mm})$, was dissolved in buffer $(20 \mathrm{~mL})$ containing 50 $\mathrm{mM}$ Tris- $\mathrm{HCl}, 0.2 \mathrm{mM} \mathrm{MnCl}_{2}$ and $20 \mathrm{mM} \mathrm{MgCl}_{2}, \mathrm{pH} 8.1$, completed with Milli-Q water.

\section{Procedure for the PP1 test}

PP1 activity was determined by measuring the rate of color developed by release of $\mathrm{p}$-nitrophenol ( $\mathrm{p}-\mathrm{NP}$ ) from $\mathrm{p}$ nitrophenol phosphate (p-NPP-SIGMA FAST lot 048H-8204). The test was performed by adding $10 \mu \mathrm{L}$ test solution to $10 \mu \mathrm{L}$ enzyme in a 96-well microtitre plate. After pre-incubation for $1 \mathrm{~min}, 180 \mu \mathrm{L}$ of substrate was added. The rate of $\mathrm{pNP}$ production was measured after $24 \mathrm{~h}$ at $405 \mathrm{~nm}$ using a Biorad plate reader at $25^{\circ} \mathrm{C}$. All enzyme tests were carried out in triplicate.

A standard curve was performed using MC-LR (SIGMA-M 2912) diluted in $70 \%$ methanol $\left(0.01-500 \mathrm{ng} \cdot \mathrm{mL}^{-1}\right)$ and measuring the percentage inhibition of enzyme activity using $70 \%$ methanol as $100 \%$ activity.

\section{PP1 test used for microcystin detection in environmental samples}

Samples from water supply reservoirs used for human consumption and recreation in Belo Horizonte metropolitan area (1955' south lat. and 4356' west long.), collected between 1999 2000, were analyzed by PP1 test. These samples were collected (Table 2) and lyophilized by the methodology indicated Sanitation Company of Minas Gerais - COPASA (8), (MG-Brazil). The data presented for the analysis of microcystin, HPLC and the mouse bioassays were carried out by COPASA (data not shown). The methodology used for toxin extraction and PP1 test was the same as described above.

\section{Data Analysis}

Statistical analysis of data was performed with SPSS for Windows (SPSS Inc). To analyse differences between the different growth experiments the Mann-Whitney $U$ test was used and a difference of $p \leq 0.05$ was taken to indicate statistical significance.

\section{RESULTS}

Using the biomass values (mg dry weight) from the culture samples, the growth rate and the doubling time were calculated for prokaryotes organisms (38), for the different concentrations of $\mathrm{P}$ and Fe. The growth curve (Fig. 1) showed that varying the concentration of phosphorus between 24 and $2 \mu \mathrm{M}$ had an affect on the culture reducing the yield from approximately 2.2 to $1.7 \mathrm{mg} / 50 \mathrm{~mL}$. A four-fold decrease in $\mathrm{P}$ concentration increased the doubling time from 34 to 55 hours, with a further three-fold decrease increasing the doubling time to 68 hours.
On the other hand, the concentration of Fe seems not to have a drastic effect on the doubling time within the duration of the experiment. A four-fold decrease increased the doubling time from 34 to 39 hours. However, after 20 days, the culture with $1 \mu \mathrm{M}$ Fe showed yellow coloration and premature death.

The microcystin production was determined using a standard curve by plotting the MC-LR concentration (ng. $\mathrm{mL}^{-1}$ ) vs $\%$ binding $\left(\mathrm{T} / \mathrm{T}_{0}\right) ;\left(\mathrm{T}_{0}=\right.$ maximum rate of color production when no MC-LR was added; $\mathrm{T}=$ rate of color production observed when MC-LR was added). The linear response for the inhibition of PP1 by MC-LR concentrations ranged from 0.1 to $10 \mathrm{ng} \cdot \mathrm{mL}^{-1}$. The concentration of MC-LR that caused a $50 \%$ inhibition of activity PP1 $\left(\mathrm{IC}_{50}\right)$ was calculated to be $0.5 \mathrm{ng} \cdot \mathrm{mL}^{-1}$ by using a standard curve ranging from $0.01-500 \mathrm{ng} \cdot \mathrm{mL}^{-1}$. The standard curve (Fig. 2) for the inhibition of PP1 by MC-LR in $70 \%(\mathrm{v} / \mathrm{v})$ methanol indicates the limit of detection of 0.01-0.05 ng. $\mathrm{mL}^{-1}$.

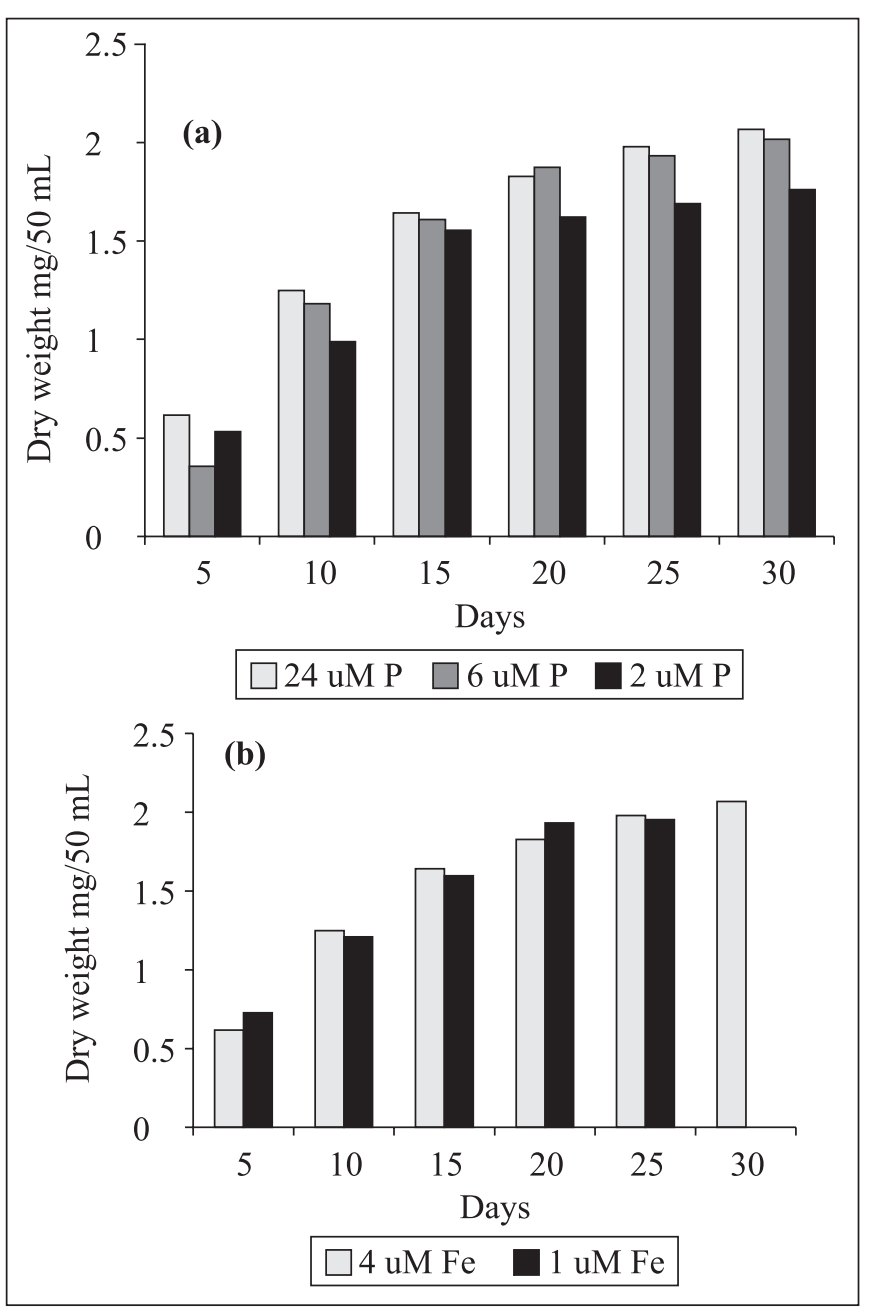

Figure 1. Effect of phosphorus (a) and iron (b) concentrations on the growth of M. aeruginosa (strain 1) in ASM-1 medium. 
The PP1 inhibition tests carried out with $M$. aeruginosa from the batch cultures produced data ranging from 0.01 to 0.025 ng.mL $\mathrm{mL}^{-1}$ (Fig. 3); all results were lower than $50 \%$ inhibition. Growth in the ASM-1 medium containing $24 \mu \mathrm{MP}$ and $4 \mu \mathrm{M} \mathrm{Fe}$ results in a relatively constant toxin production throughout the growth curve and lowering the phosphorus concentration affected the toxin production during first 20 days. For the all the growth experiments, there was no significant correlation $(p<0.05)$ between biomass increment and microcystin production.

The PP1 inhibition test confirmed the presence of microcystin in bloom samples (Table 1) previously analyzed but not quantified by HPLC and bioassays in mice. All the samples showed microcystin levels of less than $1 \mathrm{ng} \cdot \mathrm{mL}^{-1}$. Tests carried out on the samples from Ribeirão das Neves (Minas Gerais, Brazil) during the dry and wet seasons, with the same cyanobacterial species dominating the bloom, demonstrated a seasonal variation in the production of microcystin (Table 2).

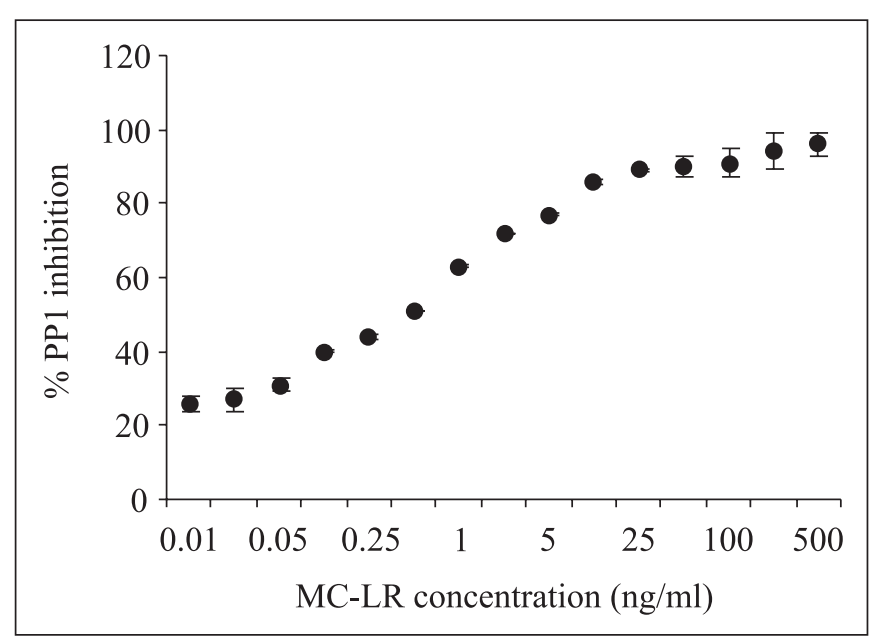

Figure 2. Standard curve for PP1 inhibition assay using MCLR. The error bar indicates the standard deviation from the mean value of the three replicates.

\section{DISCUSSION}

Many studies show that cyanobacteria produce more toxins when conditions are favorable for growth $(6,26,29,33)$. As microcystin biosynthesis is considered a secondary metabolite, most of the nutrients are use in primary metabolism for growth and maintenance of the cyanobacterial cells. During the current growth experiments carried out with different concentrations of $\mathrm{P}$ and $\mathrm{Fe}$, no significant growth rates (Figs. 1a and b) were observed.

In this study, as the only difference observed was a reduction in the culture life from 30 to 20 days in the experiment with reduced iron. This would suggest two things: firstly that the level of Fe in the ASM-1 medium is in excess and that any limited reduction does not have a significant effect on cell growth; or secondly that cyanobacteria have developed systems for the efficient use of $\mathrm{Fe}$, normally limiting in the aqueous

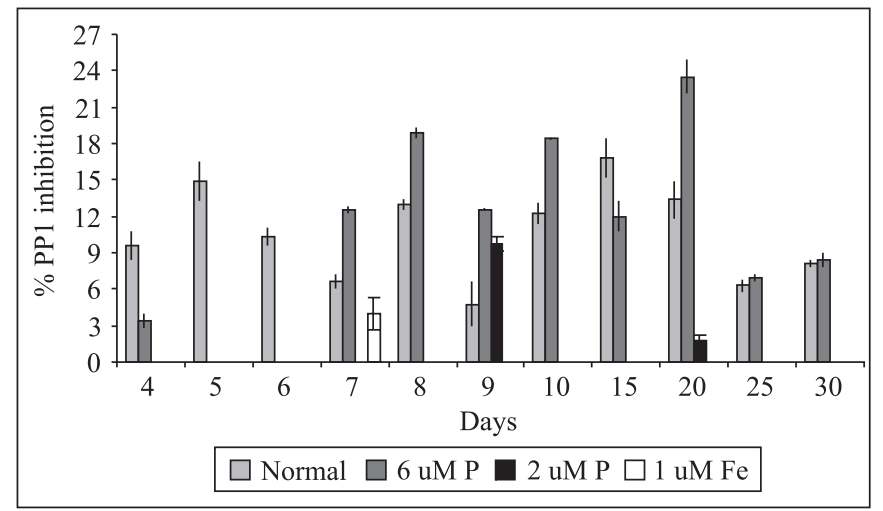

Figure 3. PP1 inhibition (\%) of microcystin produced by $M$. aeruginosa under controlled growth conditions with different concentrations of $\mathrm{P}$ and Fe. The normal medium is the ASM-1 medium ( $24 \mu \mathrm{M}$ of $\mathrm{P}$ and $4 \mu \mathrm{M}$ of $\mathrm{Fe})$. The error bar indicates the standard deviation from the mean value of the three replicates.

Table 1. PP1 Inhibition test, HPLC and mice bioassay in environmental bloom samples from the metropolitan region of Belo Horizonte, State of Minas Gerais - Southeast, Brazil

\begin{tabular}{lclccc}
\hline \multicolumn{1}{c}{ Sampling site } & Sampling Date & \multicolumn{1}{c}{ Dominant } & Bioassays* & HPLC* & $\begin{array}{c}\text { MC-LR equivalents } \\
\left(\eta \text { g.mL }^{-1} \text { by PP1 test }\right.\end{array}$ \\
\hline Ribeirão das Neves & July - 1999 & Microcystis flos-aquae & Detected - NQ & Detected - NQ & \pm 1.0 \\
Vargem das flores & August - 1999 & Microcystis flos-aquae & Detected - NQ & Detected - NQ & $<0.01$ \\
Carmo do Rio Claro & October - 1999 & Microcystis viridis & Detected - NQ & Detected - NQ & \pm 1.0 \\
Três Marias & July -2000 & Oscillatoria limnetica & Not tested - NT & Not tested - NT & ND \\
Três Marias & August - 1999 & Microcystis wesenbergii & Detected - NQ & Detected - NQ & \pm 0.5 \\
\hline
\end{tabular}

$\mathrm{ND}=$ Not detected; $\mathrm{NQ}=$ Not Quantified; $\mathrm{NT}=$ Not tested; * $=$ Sanitation Company of Minas Gerais assays. 
Table 2. PP1 Inhibition test carried out on environmental samples from the Ribeirão das Neves, State of Minas Gerais - Southeast, Brazil.

\begin{tabular}{cllcc}
\hline Local & \multicolumn{1}{c}{ Date } & Dominant species & $\begin{array}{c}\text { \% Inhibition } \\
\text { PP1 test }\end{array}$ & $\begin{array}{c}\text { MC-LR equivalents } \\
\left(\eta g . \mathrm{m}^{-1}\right)^{*}\end{array}$ \\
\hline Ribeirão das Neves-MG & September/2000 Dry season & Microcystis flos-aquae & $84 \%$ & $>10<25$ \\
Ribeirão das Neves-MG & January/2000 Wet season & Microcystis flos-aquae & $96 \%$ & \pm 100 \\
\hline
\end{tabular}

* = Calculated from the PP1 test standard curve.

environment. Pierson et al. (26) explored the influence of iron on cyanobacterial growth, concluding that high iron concentrations may stimulates photosynthesis in some cyanobacteria and reduced iron concentrations may strongly inhibited photosynthesis in others, resulting in premature death of the culture.

A low level of microcystin production was detected throughout the majority of the variations in $\mathrm{P}$ and $\mathrm{Fe}$ concentrations, but did not rise with an increase in the biomass of the culture. The results obtained from the PP1 inhibition tests demonstrated that the variations in $\mathrm{P}$ and $\mathrm{Fe}$ concentrations had a greater effect on the production of microcystin by the cyanobacterial cells (Fig. 3). According to Sivonen (32) the moment when the microcystin concentration is highest does not necessarily coincides with the highest cyanobacterial biomass, but to an increase in the proportion of the microcystin produces within the population. The relationship between the domination of species or strains and the quantity and type of microcystin within the medium can change in response to the nutritional status of the environment and the incidence and intensity of the light. These phenomena can explain the lack of correlation between biomass and microcystin production $(18,27)$. Variations in the microcystin concentration, during a period of $24 \mathrm{~h}$, have been observed in function of the temperature and light, as well as the depth of the water column sampled $(18,20)$.

As no microcystin was detected at $1 \mathrm{uM} \mathrm{Fe}$, only on the seventh day of growth when the PP1 inhibition was lower than $5 \%$, the influence of light can be eliminated as all the cultures were grown under the same light period and intensity (30 $\left.\mu \mathrm{E} \cdot \mathrm{m}^{2} \cdot \mathrm{s}^{-1}\right)$. Utkilen and Gjolme (33), noted that a decrease in the iron concentration within the medium (3.4-1.0 $\left.\mu \mathrm{g} . \mathrm{L}^{-1}\right)$ caused a decrease in toxin production by $M$. aeruginosa, and that iron uptake was dependent of light intensity.

Lukac and Aegerter (22) supported the theory that, low concentrations of $\mathrm{Fe}(\leq 2.5 \mu \mathrm{M})$ have a much more pronounced effect on growth than toxin yield. These low Fe concentrations induced the cells to grow significantly more slowly than standard conditions; however, more toxin was produced (20-40\%). When iron was supplied after a lag in growth, toxin synthesis was enhanced to up to $138 \%$. Iron is required by all cyanobacterial metabolic systems $(22,33)$. Using our strain the results show that lower iron concentration results in premature death of the culture and microcystin was not detected; this effect showed that iron is essential for primary metabolism, photosynthesis and chlorophyll synthesis. On the other hand Lukac and Aergerter, (22) noted an increase in toxin production with lower iron concentrations, although the growth rate was lower. The discrepancy between this and the present data could be due to the different strains used, with $\mathrm{Fe}$ at $1 \mu \mathrm{M}$ having a negative effect on microcystin production in our cyanobacterial strain.

Phosphate concentration is an important factor in the eutrophization of water bodies and also seems to affect toxin production in cyanobacteria $(31,34)$. In our experiments, the reduction of phosphorus in the medium did not significantly influence growth rates, but the production of microcystin was not significantly affected by lowering the $\mathrm{P}$ concentrations (Fig. 3). Other authors have also observed that a reduction in phosphorus levels slightly decreased the toxicity of $M$. aeruginosa $(6,25)$. This would suggest that growth and microcystin production increase with increasing phosphorus levels. This only serves to emphasize the critical role of $\mathrm{P}$ concentration in the speed with which a bloom can dominate eutrophic waters. The reduction of phosphorus concentrations in bodies of water would not only decrease the cyanobacterial biomass but also decrease toxin production (5). In contrast, Wicks and Thiel (37) negatively correlated P and microcystin concentration in batch culture of Microcystis aeruginosa. Oh et al. (25), observed that reducing the P concentration to $6 \mu \mathrm{M}$ reduced the growth of $M$. aeruginosa, but the microcystin content increased, suggesting that $\mathrm{P}$ is an important factor in microcystin production. Our results showed that the highest microcystin concentration was obtained after 20 days growth at $6 \mu \mathrm{MP}$ (Fig. 3).

During the analysis of the environmental samples, the PP1 test was effective in confirming the presence and the quantifying microcystin, with a range of concentrations being observed with different species of cyanobacteria isolated in the region around Belo Horizonte (Table 1). The presence of toxin in the environmental samples previously analyzed by bioassays and HPLC was confirmed by PP1 inhibition, with the toxin concentration for genus Microcystis reaching $1 \mathrm{ng} \cdot \mathrm{mL}^{-1}$. These values are inside than the range acceptable by the WHO and 
the Ministério da Saúde - (Brazil), which regulates toxin concentration and cyanobacteria blooms in fresh water in Brazil. In the case of the samples containing the genus Oscillatoria no toxin was detected above the detection limit of the PP1 test. Two environmental samples, taken from the same location (Ribeirão das Neves, MG-Brazil) and in different seasons, showed that there was an increase, over 4 times, in the toxin produced by Microcystis flos-aquae in wet season (Table 2). In Brazil, more specifically in southeast, the wet season is characterized by an increase in the temperature and higher precipitation, conditions that favor bloom formation and in many cases, high microcystin production. It can be seen that regulating iron and phosphorus levels in water bodies could reduce the toxin production, although other environmental factors also contribute to high toxin production. Thus it is necessary to investigate the complex cianobacterial response to environmental mineral levels.

We believe that the PP1 inhibition test can be used for a rapid and inexpensive method for the detection of microcystin in fresh water and bloom samples, for monitoring toxin levels in potentially contaminated environments.

\section{ACKNOWLEDGEMENTS}

The authors acknowledge the support of research grants from the Fundação de Amparo à Pesquisa do Estado de São Paulo (FAPESP) for VPSA (Process 00/09111-0) and DHM (Process 97/13242-8 and 98/04917-4), CNPQ for the grant for $\mathrm{KC}$. The Universidade Federal do Rio de Janeiro for providing the Microcystis aeruginosa and Fernando Jardim (COPASA Sanitation Company of Minas Gerais) for providing the environmental samples from Belo Horizonte and the results of mice bioassay and HPLC tests.

\section{RESUMO}

\section{Teste colorimétrico usado para o monitoramento de microcistina em cultivo de cianobactérias e em amostras de florações ambientais do sudeste do Brasil}

Microcistinas (MC) são heptapeptídeos de ação neuro e hepatotóxica produzidas por alguns gêneros de cianobactérias em determinadas condições físico-químicas do ambiente e são responsáveis pela morte e intoxicação de animais e humanos. A detecção de MC em água destinada ao consumo no Brasil ainda não é realizada na maioria dos estados brasileiros. O teste de inibição de proteína fosfatase tipo 1 (PP1) por MC é um método colorimétrico simples, rápido e de boa reprodutibilidade. Para testar a aplicação do teste PP1 foram realizados estudos de crescimento de cianobactérias em bioreator com meio ASM-1 dentro de condições controladas de crescimento (12/12h luz/ escuro usando $30 \mu \mathrm{E} . \mathrm{m}^{2} \cdot \mathrm{s}^{-1}$ de intensidade luminosa e temperatura constante de 23C) utilizando Microcystis aeruginosa (estirpe 1., UFRJ- produtor de MC). Variaram-se as concentrações de fósforo (P) em 24, 6 e $4 \mu \mathrm{M}$ e de ferro (Fe) em 4 e $1 \mathrm{mM}$. Uma curva padrão de inibição de PP1 pela MC-LR foi construída, tendo como limite de detecção 0.01 ng.mL ${ }^{-1}$. Em meio normal de crescimento $(24 \mu \mathrm{MPe} 4 \mu \mathrm{M} \mathrm{Fe})$ para Microcystis aeruginosa, a produção de MC foi detectada continuamente durante o crescimento da cultura. A maior concentração de MC foi observada na concentração de $6 \mu \mathrm{M}$ P e não foi detectada na concentração de $1 \mu \mathrm{M} \mathrm{Fe}$. Amostras de florações ambientais, da região sudeste do Brasil (Belo Horizonte/MG), coletadas em corpos d'água utilizados para abastecimento e consumo humano, foram testadas e quantificadas para a presença de microcistina pelo teste colorimétrico PP1. A concentração de microcistina variou entre quantidades não detectáveis pelo método até 100 ng. $\mathrm{mL}^{-1}$ em amostras de floração da espécie Microcistis flos-aquae.

Palavras-chave: proteína fosfatase, Microcystis aeruginosa, inibição e ambiente

\section{REFERENCES}

1. An, J.; Carmichael, W. W. Use of colorimetric protein phosphatase inhibition assay and enzyme linked immunosorbent assay for the study of microcystins and nodularins. Toxicon, 32(12), 1495-1507, 1994.

2. Ash, C.; Mackintosh, C.; Mackintosh, R.; Fricker, C. R. Use of protein phosphatase inhibition test for the detection of cianobacterial toxins in water. Water Sci. Technol., 31(5/6), 51-53, 1995.

3. BRASIL. Ministério da Saúde - Portaria n. 518 GM/04. Diário Oficial, 25/03/2004

4. Carmichael, W.W. Cyanobacterial secondary metabolites - the cyanotoxins. J. Appl. Bacteriol., 71, 445-459, 1992.

5. Chorus, I.; Bartran, J. Toxic Cyanobacteria in water: a guide to public health consequences, monitoring and management. WHO, London, 1999, 416p.

6. Codd, G.A.; Poon, G.K. Cyanobacterial toxins. In: Rogers, L.J.; Gallon, J.R. (eds.) Biochemistry of the algae and cyanobacteria. Oxford University Press, Oxford, 1988. p.283-296.

7. Codd, G.A.; Ward, C.J.; Bell, S.G. Cyanobacterial toxins: occurrence, modes of action, health effects and exposure routes. Arch. Toxicol. Supplement., 19, 399-410, 1997.

8. COPASA MG. Norma Técnica T.126 - Coleta de amostra de águas para análise hidrobiológica. Belo Horizonte, 1992.

9. Dawson, R.M. The toxicology of microcystins. Toxicon, 36(7), 953 962, 1998 .

10. Dunn, J. Algae kills dialysis patient in Brazil. Bri. Med. J., 312 (7040), 1183-1184, 1996

11. Falconer, I.R.; Jackson, A.R.B.; Langley, J.; Runnegar, M.T. Liver phatology in mice in poisoning by the blue-green algae Microcystis aeruginosa. Aust. J. Biol. Sci., 34, 179 -187, 1981.

12. Falconer, I.R. Health problems from exposure to cyanobacteria: a proposed safety guideline for drinking and recreational water. In: Cood, G.A.; Jefferies, T.M.; Keevil, C.W. (eds). Detection methods for cyanobacterial toxins. The Royal Society of Chemistry, London, 1994, p.3-10.

13. Fawell, J.K.; Hart, J.; James, H.A.; Parr, W. Blue-green algae and their toxins analysis, toxicity, treatment and environmental control Water Supp., 11(3/4), 109-121, 1993. 
14. Gorham, P.R.; McLachlan, J.; Hammer, U.T.; Kim, W.K. Isolation and culture of toxic strains of Anabaena flos-aquae (Lyngb.) Breb. Verhandlungen - Internationale Vereinigung fur Theoretische und Angewandte Limnologie, 15, 796-804, 1964

15. Harada, K.; Oshikata, M.; Uchida, H.; Suzuki, M.; Kondo, F.; Satao, K.; Ueno, Y.; Yu, S.; Chen, G.; Chen, G.C. Detection and Identification of microcystins in the drinking water of Haimen City, China. Nat. Toxin., 4, 277-283, 1996.

16. Heresztyn, T.; Nicholson, B.C. Determination of cyanobacterial hepatotoxins directly in water using a protein phosphatase inhibition assay. Water Res., 35(13), 3049-3056, 2001.

17. Honkanen, R.E.; Zwillers, J.; Moore, R.A.; Daily, S.L.; Khatra, B.S.; Dukelon, M.; Boyton, A.L. Characterization of microcystin-LR, a potent inhibitor of type 1 and $2 \mathrm{~A}$ protein phosphatase. J. Biol. Chem., 265(19), 19401-19404, 1990.

18. Jones, G.J.; Falconer, I.R. Factors affecting the production of toxin by cyanobacteria. Final grant report to the land and water resources Research and Development Corporation, Camberra, Australia. 1994, p. 42 .

19. Jones, G.J.; Orr, P.T. Release and degradation of microcystin following algicide treatment of a Microcystis aeruginosa bloom in a recreational lake, as determined by HPLC and protein phosphatase inhibition assay. Water Res., 28(4), 871-876, 1994.

20. Kotak, B.G.; Lam, A.K.Y.; Prepas, E.E.; Kenefik, S.L.; Hrudey, S.E. Variability of the hepatotoxin, microcystin-LR, in hypereutrophic drinking water lakes. J. Phycol., 31, 128-263, 1995.

21. Lahti, K.; Rapala, J.; Kivimaki, A.L.; Kukkonen, J.; Niemala, M.; Sivonen, K. Occurrence of microcystins in water sources and treats drinking water of Finnish waterworks. Water Sci. Technol., 43(12), 225-228, 2001

22. Lukac, M.; Aegerter, R. Influence of trace metals on growth and toxin production of Microcystis aeruginosa. Toxicon, 31(3), 293305, 1993.

23. Meibner. K.; Dittman, E.; Borner, T. Toxic and non-toxic strains of the cyanobacterium Microcystis aeruginosa contain sequences homologous to peptide synthetase genes. FEMS Microbiol. Lett., 135, 295-303, 1996.

24. Metcalf, J.S.; Steven, G.; Cood, G.A. Colorimetric immuno-protein phosphatase inhibition assay for specific detection of microcystin and nodularins of Cyanobacteria. Appl. Environ. Microbiol., 67, 904-909, 2001.

25. Oh, H.M.; Seog, J.L.; Jeehwan, K.; Heesik, K.; Byungdae, Y. Seasonal Variation and indirect monitoring of microcystin concentration in Daechung Reservoir, Korea. Appl. Environ. Microbiol., 67, 14841489,2001

26. Pierson, B.K.; Parenteau, M.N.; Griffin, B.M. Phototrophs in highiron-concentration microbial mats: physiological ecology of phototrophs in an iron-depositing hot spring. Appl. Environ. Microbiol., 65(12), 5474-5483, 1999.

27. Rapala, J.; Sivonen, K.; Lyra, C.; Niemala, S.I. Variation of microcystins, cyanobacterial hepatoxins, in Anabaena spp. As a function of growth stimuli. Appl. Environ. Microbiol., 63(6), 22062212, 1997.

28. Runnegar, M.T.; Kong, S.; Berndt, N. Protein phosphatase inhibition and in vivo hepatotoxicity of microcystins. Am. J. Physiol., 265(2), G224-G230, 1993.

29. Schreurs, H. Cyanobacterial dominance, relation to eutrophication and lake morphology. Amsterdam, 1992, 156p. (Ph.D. Thesis, University of Amsterdam).

30. Serres, M.H.; Fladmark, K.E.; Doskeland, S.O. An ultrasensitive competitive binding assay for the detection of toxins affecting protein phosphatases. Toxicon, 38, 347-360, 2000.

31. Sivonen, K. Effects of light, temperature, nitrate, orthophosphate and bacteria growth of and hepatoxin production by Oscillatoria agardhii strains. Appl. Environ. Microbiol., 56(9), 2658-2666, 1990.

32. Sivonen, K. Cyanobacterial toxins and toxin production. Phycologia, 35(96), 12-24, 1996.

33. Utkilen, H.; Gjolme, N. Iron-stimulated toxin production in Microcystis aeruginosa. Appl. Environ. Microbiol., 61(2), 797-800, 1995.

34. Watanabe, M.F.; Oishi, S. Effects of environmental factors on toxicity of cyanobacterium (Microcystis aeruginosa) under culture conditions. Appl. Environ. Microbiol., 49, 1342-1344, 1985.

35. Watanabe, M.F.; Tsuji, K.; Watanabe, Y.; Harada, K.; Suzuki, M. Release of heptapeptide toxin (microcystin) during the decomposition of Microcystis aeruginosa. Nat. Toxins., 1, 48-53, 1992.

36. Ward, C.J.; Beattie, K.A.; Lee, E.Y.C.; Codd, G.A. Colorimetric protein phosphatase inhibition assay of laboratory strains and natural blooms of cyanobacterial: comparisons with high-performance liquid chromatographic analysis for microcystins. FEMS Microbiol. Lett., 153, 465-473, 1997.

37. Wicks, R.J.; Thiel, P.G. Environmetal factors effecting the production of peptide toxins in floating scums of the cyanobacterium Microcystis aeruginosa in a hypertrophic African reservoir. Environ. Sci. Technol., 24, 1413-1418, 1990.

38. White, D. The physiology and biochemistry of prokaryotes. Oxford University Press, New York, 1995. 378p.

39. Wong, B.S.F.; Lam, P.K.S.; Xu, L.; Zhang, Y.; Richardson. B.J. A colorimetric assay for screening microcystin class compounds in aquatic systems. Chemosphere, 38(5), 1113-1122, 1999.

40. Xu, L.H.; Lam, P.K.S.; Chen, J.P.; Wong, B.S.F.; Zhang, Y.Y.; Wu, R.S.S.; Harada, K.I. Use of protein phosphatase inhibition assay to detect microcystins in Donghu Lake and fish pond in China. Chemosphere, 41, 53-58, 2000. 